www.jmscr.igmpublication.org

Index Copernicus Value: 79.54

ISSN (e)-2347-176x ISSN (p) 2455-0450

crossref DOI: https://dx.doi.org/10.18535/jmscr/v7i6.109

Journal Of Medical Science And Clinical Research

IGM Publication

An Official Publication of IGM Publication

\title{
Effect of Medical college environment and curriculum on Non cognitive scores of Students requiring additional curricular support
}

\author{
Authors \\ Ramesh $\mathbf{R}^{1}$, Sethuraman $\mathrm{KR}^{2}$, Ezhumalai $\mathrm{G}^{3}$
}

${ }^{1}$ Professor, Department of Biochemistry, JIPMER, Puducherry \& Research Scholar, Medical Education Unit, Mahatma Gandhi Medical College and Research Institute, Sri Balaji Vidyapeeth, Puducherry

${ }^{2}$ Endowed Distinguished Senior Professor of General Medicine, AIMST University, Malaysia

${ }^{3}$ Sr. Statistician \& Research Consultant, Sri Balaji Vidyapeeth, Puducherry

\begin{abstract}
Background: Sociologists Bowls and Gint is identified Non cognitive variables as skills other those measured by standard cognitive scores and it concentrates more on characteristics such as adjustment, motivation and students perception. Though the interest in Non cognitive skills dates back several decades many researchers have still questioned the stability of Non cognitive skills across different situation and there is no conclusive evidence which of the diverse characteristics is the one crucial to improve or facilitate attainment in all domains. Based on the this background of varied findings about Non cognitive scores our work was planned to compare the impact of college environment and curriculum on twelve Non cognitive variables among first MBBS students who do and do not require additional curricular support.

Methodology: Adapted version of Sedlacek et al questionnaire was applied to assess the 12 Non cognitive scores at the beginning and at the end of the 4th month of the whole batch which included 500 first year $M B B S$ students out of which 283 students where included in SNACS group. Cornbrash's alpha was done for validating the questionnaire and the data was analysed appropriately paired't test, students $t$ test and ANOVA.

Results: The baseline and the 4th month Total Non cognitive scores of the three SNACS group students where significantly less when compared to Non SNACS group. Individual Non cognitive scores were also less when compared to SNSCS group of students. The decrease was more for some specific variables when compared to others

Conclusion: The study shows Non cognitive variables are affected by the college environment and curriculum and admission counsellors should also take into consideration Non cognitive scores for making a policy while selection of students into the course.

Keywords: Non Cognitive scores Medical Education.
\end{abstract}

\section{Introduction}

The concept of Non Cognitive variables was introduced by sociologists Bowles and Gintis in 1976 to focus on skills other than those measured by standard cognitive scores ${ }^{[1]}$ and it evaluates characteristics such as adjustment, motivation and students perception ${ }^{[2]}$. Though interest in Non cognitive skills dates back several decades and spans multiple disciplines, research on Non cognitive skills as a factor affecting students achievement is still in infancy ${ }^{[3,4]}$. Janch's and his colleagues in 1979 found that Non cognitive skills 
showed almost identical effect size as cognitive skills in predicting academic success ${ }^{[5]}$ and some studies even predicted that Non cognitive trait might be even more important than cognitive skills in determining academic outcome of students ${ }^{[6]}$. But still there is debate and little agreement about the malleability, reliability and the importance of individual variables of Non cognitive skills. There is no conclusive evidence which of the diverse characteristics is the one crucial to improve or facilitate attainment across all domains. Educational researchers have also documented unexpected patterns while assessing Non cognitive scores of students for which they attributed the variability of average baseline scores among students belonging to different place and school ${ }^{[7]}$.

A positive school environment has been associated with better student behavior, academic achievement, and graduation rates ${ }^{(8-11)}$. School learning environments can complement noncognitive skills by fostering such traits as grit, tenacity, and perseverance ${ }^{(12)}$. College students are particularly vulnerable during the initial years on campus as they have to adapt to higher academic expectation and renegotiate their metacognitive skills and of belonging in new and unfamiliar environment. As practice and policy gets modernised and improves however research on Non cognitive skills remain in infancy

Based on this background of varied findings about Non Cognitive scores our work was planned to compare the impact of college environment and curriculum on twelve Noncognitive variables among First MBBS students who require additional curricular support (SNACS) and students who do not require additional curricular support (Non SNACS).

\section{Study Design}

This is a prospective cohort study carried out among two batches of First year MBBS students and involved 250 students from each batch were followed up for a period of 4 months.

\section{Data collection}

Adapted version of the Sedlacek et al questionnaire was applied to whole batch on the day of joining to get the baseline Non cognitive scores after performing appropriate validation and reliability tests to assess 12 Non cognitive variables (Fig1). At the end of $4^{\text {th }}$ month normalisation of their academic scores were done by calculating $\mathrm{Z}$ score. Students who scored below $40 \%$ in formative assessments conducted during the period of $4^{\text {th }}$ months were identified as students requiring additional curricular support (SNACS) and the rest where included as NON SNACS group (217students). The SNACS group students where again divided into three groups. Group1 (121 students) are the students who scored below $40 \%$ in only in Biochemistry (0ne subject), Group II (90 students) the students who have scored below $40 \%$ in Biochemistry and Anatomy (2 Subjects) and students who have scored below $40 \%$ in all the three subjects Anatomy, Physiology and Biochemistry were labelled as Group III (62 students)

\section{Data Analysis}

Cronbach's alpha was done for validating the questionnaire and Student ' $t$ ' test was done to detect any significant difference in Non cognitive scores among SNACS and NON SNACS group. Paired' test was performed to assess for any significant change in Non cognitive scores from the baseline and at the end of 4 months within the groups. ANOVA was performed to study the difference in Non cognitive scores from the baseline and at the end of 4 months among the groups.

\section{Results}

The study was carried out among 500 First MBBS students to study the effect of college environment and curriculum on Non cognitive scores among students who do and do not require additional curricular support. The baseline and $4^{\text {th }}$ month TOTAL Non cognitive scores of the three SNACS group students where significantly less when compared to Non cognitive scores of Non SNACS 
group of students (fig1). Individual Non cognitive scores were also less in SNACS groups both at the beginning and at the end of $4^{\text {th }}$ month when compared to Non SNACS group (Table1\&2). The decrease was more for Non cognitive variables like study methods and effectiveness, involvement with faculty and academic support, positive selfconcept, perseverance, realistic self-appraisal and emotional intelligence both at the beginning and at the end of the $4^{\text {th }}$ month with effect size greater than 2.(Table2).

Paired ' $t$ ' test was performed to find out any significant difference between baseline and $4^{\text {th }}$ month Non cognitive within the three SNACS group of students. Non Cognitive variables like Emotional intelligence, study methods and effectiveness, strong support system, positive self concept, perseverance, realistic self appraisal showed greater decrease at the end of the $4^{\text {th }}$ month with effect size greater than 2 ( table 3 ). Effect size of group III was greater than group I and II for all non cognitive variables.

Among the Non SNACS group Non Cognitive variables like knowledge acquired in field, study methods and effectiveness, perseverance significantly increased while involvement with extracurricular activity decreased at the end of the $4^{\text {th }}$ month.

ANOVA performed to document any significant difference in Non cognitive scores among the three SNACS group both at the beginning and at the end of the $4^{\text {th }}$ month showed a ' $F$ ' value ranging from 200 to 540 (Fig2). The difference among the groups where more pronounced at the end of the $4^{\text {th }}$ month than at the base line. Non cognitive variables like Emotional intelligence, Realistic self appraisal, Strong support system, positive self concept and perseverance showed the maximum difference. Post Hoc test showed the difference was maximum between Group I and III than for group I and II.

Table 1: List of Non-cognitive variables

\begin{tabular}{|l|l|}
\hline 1 & Realistic self appraisal \\
\hline 2 & Positive self concept \\
\hline 3 & Preference in long term goals \\
\hline 4 & Having a strong support person \\
\hline 5 & Interest and ability to relate to others \\
\hline 6 & Emotional intelligence \\
\hline 7 & Involvement with faculty and academic support \\
\hline 8 & Leadership experience \\
\hline 9 & Involvement in extracurricular activity. \\
\hline 10 & Knowledge acquired in the field. \\
\hline 11 & Study methods and effectiveness \\
\hline 12 & Perseverance. \\
\hline
\end{tabular}

Table 2: Descriptive statistics of Non-Cognitive variables

\begin{tabular}{|c|c|c|c|c|c|c|c|c|}
\hline \multirow{2}{*}{$\begin{array}{l}\text { Groups } \\
\text { Sub Groups }\end{array}$} & \multicolumn{3}{|c|}{ SNACS @ baseline (MEAN \pm SD) } & \multicolumn{3}{|c|}{ SNACS @4 MONTHS (MEAN \pm SD) } & \multirow{2}{*}{$\begin{array}{c}\text { NON SNACS @ } \\
\text { BASELINE } \\
(\mathrm{MEAN} \pm \mathrm{SD})\end{array}$} & \multirow{2}{*}{$\begin{array}{c}\text { NONSNACS @ } \\
4 \text { MONTHS } \\
(\mathrm{MEAN} \pm \mathrm{SD})\end{array}$} \\
\hline & GROUP I & GROUP II & GROUP III & GROUP I & GROUP II & GROUP III & & \\
\hline \multicolumn{9}{|l|}{ VARIABLES } \\
\hline Strong support system & $58.81 \pm 3.10$ & $52.83 \pm 2.02$ & $47.42 \pm 2.06$ & $50.04 \pm 3.21$ & $46.13 \pm 2.41$ & $41.91 \pm 1.9$ & $86.3 \pm 8.2$ & $85.1 \pm 7.6$ \\
\hline $\begin{array}{l}\text { Study methods and } \\
\text { effectiveness }\end{array}$ & $57.41 \pm 3.00$ & $52.32 \pm 2.12$ & $48.63 \pm 4.42$ & $48.80 \pm 2.68$ & $42.32 \pm 2.13$ & $40.22 \pm 2.39$ & $78.6 \pm 5.8$ & $85.2 \pm 6.4$ \\
\hline $\begin{array}{l}\text { Involvement with } \\
\text { extracurricular activity }\end{array}$ & $69.83 \pm 6.37$ & $62.62 \pm 2.52$ & $58.28 \pm 2.78$ & $60.21 \pm 7.30$ & $57.12 \pm 2.72$ & $52.67 \pm 2.78$ & $84.2 \pm 9.6$ & $70.2 \pm 6.8$ \\
\hline $\begin{array}{l}\text { involvement with faculty } \\
\text { and academic support }\end{array}$ & $58.83 \pm 2.75$ & $52.43 \pm 2.51$ & $48.44 \pm 2.39$ & $49.10 \pm 2.19$ & $46.93 \pm 2.04$ & $43.69 \pm 2.11$ & $82.4 \pm 9.2$ & $81.7 \pm 8.6$ \\
\hline $\begin{array}{l}\text { knowledge acquired in the } \\
\text { field }\end{array}$ & $60.42 \pm 3.20$ & $54.56 \pm 1.81$ & $50.85 \pm 3.04$ & $54.81 \pm 2.71$ & $50.12 \pm 1.89$ & $46.45 \pm 2.82$ & $70.2 \pm 6.8$ & $80.6 \pm 6.6$ \\
\hline leadership experience & $60.81 \pm 3.14$ & $54.55 \pm 1.83$ & $54.15 \pm 2.51$ & $54.03 \pm 2.31$ & $50.24 \pm 1.08$ & $46.83 \pm 2.37$ & $70.4 \pm 5.4$ & $70.8 \pm 5.9$ \\
\hline positive self concept & $48.20 \pm 2.91$ & $45.32 \pm 2.21$ & $40.28 \pm 2.75$ & $39.82 \pm 2.52$ & $32.78 \pm 1.56$ & $29.44 \pm 2.66$ & $70.8 \pm 6.8$ & $69.9 \pm 5.8$ \\
\hline $\begin{array}{l}\text { preference in long term } \\
\text { goals }\end{array}$ & $60.27 \pm 4.01$ & $56.22 \pm 1.73$ & $50.69 \pm 1.94$ & $56.61 \pm 2.81$ & $51.35 \pm 1.69$ & $46.19 \pm 1.98$ & $82.4 \pm 8.1$ & $81.8 \pm 7.4$ \\
\hline preserverance & $56.62 \pm 2.76$ & $52.43 \pm 2.31$ & $46.21 \pm 2.66$ & $49.22 \pm 2.04$ & $46.38 \pm 2.18$ & $40.85 \pm 3.23$ & $73.6 \pm 5.8$ & $85.4 \pm 6.2$ \\
\hline realistic self appraisal & $60.81 \pm 2.60$ & $55.12 \pm 2.01$ & $50.33 \pm 2.29$ & $55.03 \pm 2.99$ & $51.03 \pm 1.27$ & $46.41 \pm 2.74$ & $83.2 \pm 6.8$ & $82.1 \pm 6.2$ \\
\hline emotional intelligence & $49.92 \pm 3.26$ & $42.56 \pm 2.21$ & $37.43 \pm 2.89$ & $38.21 \pm 2.32$ & $35.09 \pm 1.27$ & $31.62 \pm 2.48$ & $79.4 \pm 9.2$ & $77.8 \pm 8.2$ \\
\hline ability to relates other & $55.21 \pm 4.31$ & $50.23 \pm 4.42$ & $45.18 \pm 3.78$ & $49.56 \pm 3.46$ & $44.12 \pm 2.76$ & $40.61 \pm 2.09$ & $77.2 \pm 5.6$ & $58.3 \pm 6.2$ \\
\hline Total Non cognitive score & $58.05 \pm 4.31$ & $52.59 \pm 4.63$ & $48.15 \pm 4.8$ & $50.57 \pm 5.23$ & $46.12 \pm 5.18$ & $42.23 . \pm 3.52$ & $78.79 . \pm 8.4$ & $79.07 . \pm 8.1$ \\
\hline
\end{tabular}




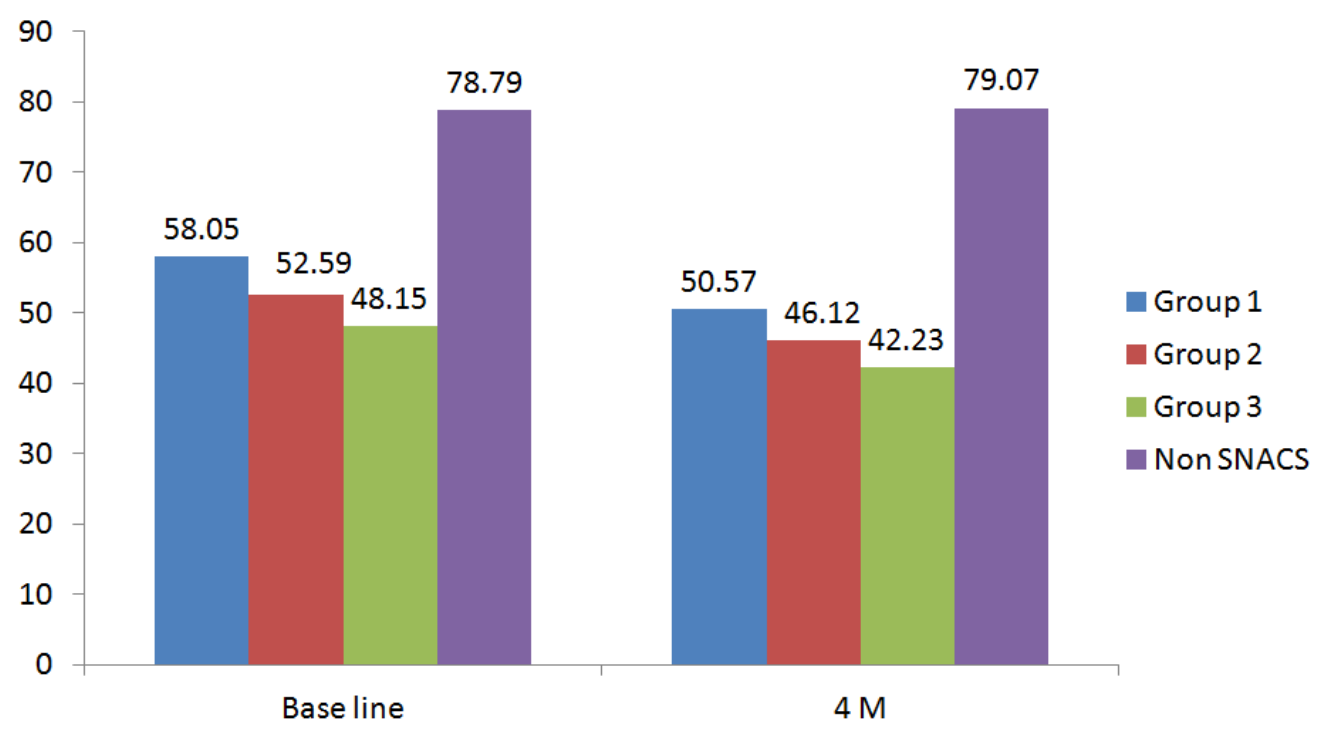

Figure.1: Comparison of baseline and 4month Total Non cognitive score mean of SNACS group with NONSNACS group

Table.3: Comparison of scores at Baseline and $4^{\text {th }}$ month among SNACS

\begin{tabular}{|c|c|c|c|c|c|c|}
\hline \multirow{2}{*}{$\begin{array}{l}\text { Groups } \\
\text { Sub Groups }\end{array}$} & \multicolumn{3}{|c|}{ SNACS baseline (Effect Size) } & \multicolumn{3}{|c|}{ SNACS 4 MONTHS (Effect size) } \\
\hline & GROUP I & GROUP II & GROUP III & GROUP I & GROUP II & GROUP III \\
\hline VARIABLES & & & & & & \\
\hline Strong support system & 1.6 & 1.4 & 1.3 & 1.8 & 1.5 & 1.6 \\
\hline Study methods and effectiveness & 2.0 & 2.4 & 1.9 & 2.3 & 2.6 & 2.6 \\
\hline Involvement with extracurricular activity & 1.0 & 1.2 & 1.2 & 1.2 & 1.3 & 1.6 \\
\hline Involvement with faculty and academic support & 2.2 & 2.2 & 2.4 & 2.4 & 2.4 & 2.6 \\
\hline Knowledge acquired in the field & 1.2 & 1.2 & 1.4 & 2.5 & 2.6 & 2.7 \\
\hline Leadership experience & 1.1 & 1.3 & 1.5 & 1.5 & 1.9 & 1.9 \\
\hline Positive self concept & 2.2 & 2.1 & 2.5 & 2.4 & 2.4 & 2.7 \\
\hline Preference in long term goals & 1.4 & 1.5 & 1.4 & 1.8 & 1.8 & 1.3 \\
\hline Perseverance & 2.3 & 2.2 & 2.2 & 2.5 & 2.4 & 2.4 \\
\hline Realistic self appraisal & 2.3 & 2.4 & 2.3 & 2.6 & 2.6 & 2.6 \\
\hline Emotional intelligence & 2.4 & 2.6 & 2.6 & 2.6 & 2.9 & 2.9 \\
\hline Ability to relates other & 1.1 & 1.1 & 1.2 & 1.3 & 1.4 & 1.5 \\
\hline Total Non cognitive score & & & & & & \\
\hline
\end{tabular}

Table.4: Comparison of Baseline and $4^{\text {th }}$ month scores among SNACS and NONSNACS group of students.

\begin{tabular}{|c|c|c|c|c|}
\hline \multirow{2}{*}{$\begin{array}{l}\text { Groups } \\
\text { Sub Groups }\end{array}$} & \multicolumn{3}{|c|}{ SNACS baseline (Effect size) } & \multirow{2}{*}{$\begin{array}{c}\text { NONSNACS } \\
\text { baseline (Effect size) } \\
\text { GROUP IV }\end{array}$} \\
\hline & GROUP I & GROUP II & GROUP III & \\
\hline \multicolumn{5}{|l|}{ VARIABLES } \\
\hline Strong support system & 2.1 & 2.3 & 2.5 & 0.06 \\
\hline Study methods and effectiveness & 2.3 & 2.5 & 2.7 & 2.20 \\
\hline Involvement with extracurricular activity & 1.6 & 1.8 & 2.0 & 2.30 \\
\hline Involvement with faculty and academic support & 2.0 & 2.2 & 2.4 & 0.03 \\
\hline Knowledge acquired in the field & 1.2 & 1.4 & 1.6 & 2.40 \\
\hline Leadership experience & 1.4 & 1.6 & 1.8 & 0.04 \\
\hline Positive self concept & 1.8 & 2.0 & 2.3 & 0.09 \\
\hline Preference in long term goals & 1.2 & 1.4 & 1.7 & 0.40 \\
\hline Perseverance & 2.0 & 2.3 & 2.6 & 2.20 \\
\hline Realistic self appraisal & 1.8 & 2.0 & 2.2 & 0.05 \\
\hline Emotional intelligence & 2.4 & 2.6 & 2.9 & 0.06 \\
\hline Ability to relates other & 1.8 & 1.7 & 1.9 & 0.02 \\
\hline Total Non cognitive score & $58.05 \pm 4.31$ & $52.59 \pm 4.63$ & $48.15 \pm 4.8$ & $48.15 \pm 4.8$ \\
\hline
\end{tabular}




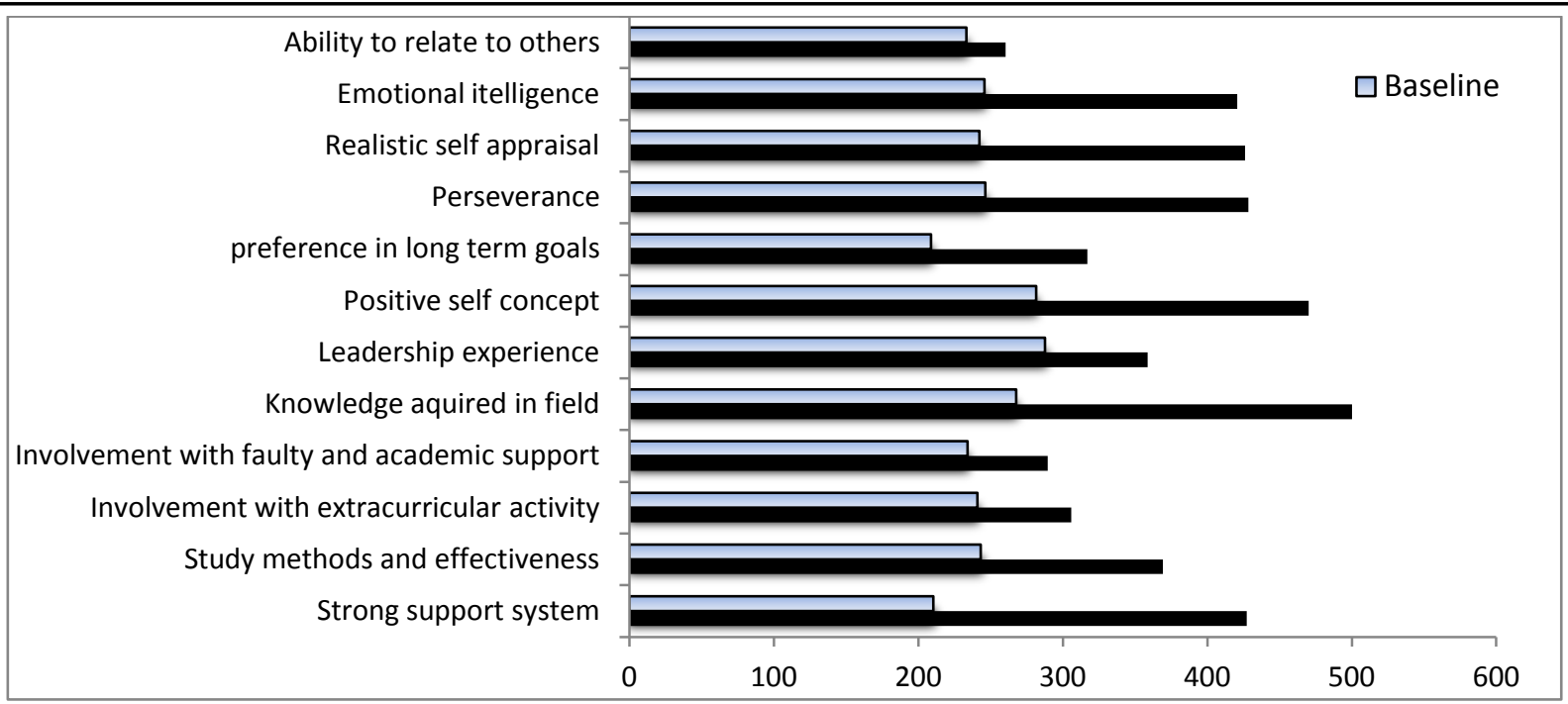

Figure 2: Comparison of baseline and 4 month Total Non cognitive score

\section{Discussion}

Environment is defined by Webster as the sum total of all surrounding of a living organism, including natural forces and other living things which provide conditions for development and growth as well as danger and damage. College environment in which students spend most of their time extent a powerful influence on students non cognitive skills as assessed by self reports, till recent past had not been considered as a factor affecting academic performance.

Students enrolled for Medical colleges enter into the new environment which includes domains like administration, academic, teaching and learning methods which are totally different from school atmosphere and to navigate these changes students should be good in experiential learning which depends on individual non cognitive skills.

Finding that teachers have effects on ability unmeasured by test scores offers a potential explanation for the impact of college environment on academic outcome ${ }^{[12]}$. Haniskeh et al, 2002 shows that cognitive and non cognitive skills are modelled as outcome of several environmental factors like household income, parental education, family size which cannot controlled by policy makers $^{[13]}$. Study conducted by Dee and west showed that college environment including class size affect students Non cognitive skills as evidenced that students in smaller classes are both less afraid to ask questions and less disruptive ${ }^{[14]}$.
In our study the scores for Non cognitive variables like study methods and effectiveness, Involvement with faculty and academic support, positive self concept, perseverance, Realistic self appraisal and emotional intelligence were less among SNACS group than Non SNACs group of students. This results are in accordance of many studies that shows that Non cognitive scores have a positive impact on students academic performance ${ }^{[15]}$.

Non cognitive variables like Emotional intelligence, Study methods and Effectiveness, Strong support system, positive self concept, Perseverance and Realistic self appraisal showed statistically significant decrease at the end of the $4^{\text {th }}$ month when compared to other variables and this shows that college environment plays an important role in shaping and improving students non cognitive skills which is in accordance with many studies.

The reason for their realistic self appraisal to be low can be explained by their difficulty to adapt to new college environment and not knowing how to identify their weakness under the given circumstances. Another reason could be that we have not adopted to a $\mathrm{T} / \mathrm{L}$ methods that makes the subject interesting. The factors that hinders them from setting goals are like not knowing their goals and not fully equipped with time management.

The reluctance to establish a strong support system may include lack of strong communication, no idea whom to contact, lack of 
motivation from parents and not able to develop good rapport with senior students. Decrease in Emotional Intelligence Score may be due to their inadequate preparedness for combating stress related to new environment and curriculum.

Study conducted by Rock off et al 2008 showed that teachers who are integral part of college curriculum play a crucial role in modelling non cognitive skills of the students ${ }^{[16]}$. They also pointed faculty development programmes to improve such skills among the students should be part of teachers education ${ }^{[17]}$. Study conducted by Hanushek et al 2012 showed that students in colleges which emphasise discipline and have transparent system for monitoring teachers and greater autonomy in hiring and staffing decisions had a higher levels of moral commitment and less disruptive behaviour ${ }^{[18]}$. These findings suggest that college education system also plays an important role in regulating non cognitive skills while it is difficult to interpret the results in a causal way.

Finally our study in accordance with others proves that classroom conditions and school environment influences students feeling of belonging, self efficacy, valuation of school work and in turn plays a vital role in improving students Non cognitive skills.

\section{Limitations}

The study was limited to only one private medical college and it is necessary to carry out a multicentric approach in the future.

\section{Conclusion}

Admission counsellors cannot rely exclusively on cognitive variables for predicting academic success of at risk students.

Future research is needed to further examine how programmes that are already in place in many colleges and universities could be modified to enhance psychological attributes that complement cognitive elements.

\section{References}

1. Bowles S, Gintis H. Schooling and Inequality from Generation to Generation. J. Political Econ. 1972 May/June; 80(3):S219-S251

2. Sedlacek WE, Sheu HB. The academic progress of undergraduate and graduate Gates Millennium Scholars and nonscholars by race and gender. Readings on Equal Education. 2008;23:143-177.

3. Forbes DP, Milliken FJ. Cognition and Corporate Governance: Understanding Boards of Directors as Strategic DecisionMaking Groups. Acad Manage Rev. 1999 Jul 1;24(3):489-505

4. Raudenbush S, Kasim R. Cognitive Skill and Economic Inequality: Findings from the National Adult Literacy Survey. Harv. Educ. Rev. 1998 April;68(1):33-80.

5. Jauch-Chara, K., M. Hallschmid, S. Schmid, N. Bandorf, J. Born, and B. Schultes. Sleep loss does not aggravate the deteriorating effect of hypoglycemia on neurocognitive function in healthy men. Psychoneuroendocrinology. 2010;35(4): 624-628.

6. Heckman J, Stixrud J, Urzua S. The effects of cognitive and non-cognitive abilities on labour market outcomes and social behavior. J. Labor Econ. 2006;24(3):411-482

7. Kyllonen PC, Bertling JP. Innovative questionnaire assessment methods to increase cross-country comparability. In: Rutkowski L, von Davier M, Rutkowski D.(eds.), Handbook of international largescale assessment: Background, technical Issues, and methods of data analysis London, England: Chapman \& Hall. 2013. p. 277-285.

8. Allensworth, E. M., and Easton, J. Q. The on-track indicator as a predictor of high school graduation. Chicago, IL: Consortium on Chicago School Research 2005. 
9. Bryk AS, Sebring PB, Allensworth E, Easton JQ, Luppescu S. Organizing Schools for Improvement: Lessons from Chicago. University of Chicago Press; 2010. 328 p.

10. Voight, A., Austin, G., and Hanson, T. (2013). A climate for academic success: How school climate distinguishes schools that are beating the achievement odds (Full Report). San Francisco: WestEd.

11. Eccles J S and Wigfield A. Motivational beliefs, values, and goals. Annu. Rev. Psychol. 2002. 53:109-32.

12. Shechtman, N., DeBarger, A. H., Dornsife, C., Rosier, S., \& Yarnall, L. Promoting grit, tenacity, and perseverance: Critical factors for success in the $21 \mathrm{st}$ century. 2013 Washington, DC: U. S. Department of Education. Retrieved from http://www.ed.gov/edblogs/technology/file s/2013/02/OET-Draft-Grit-Report-2-1713.pdf.

13. Heckman JJ, Kautz T. Fostering and Measuring Skills: Interventions That Improve Character and Cognition [Internet]. National Bureau of Economic Research; 2013 Nov. Report No.: 19656. Available from: http://www.nber.org/papers/w19656

14. Craig CJ. Narrative inquiry in teaching and teacher education. In: Narrative Inquiries into Curriculum Making in Teacher Education [Internet]. Emerald Group Publishing Limited; 2011. p. 19-42. (Advances in Research on Teaching; vol. 13). Available from: http://www.emeraldinsight.com/doi/abs/10 .1108/S1479$3687 \% 282011 \% 2900000130005$
15. Hanushek 2002 OurSchOurFuture.pdf [Internet]. [cited 2017 Dec 13]. Available from:

http://hanushek.stanford.edu/sites/default/f iles/publications/Hanushek\%202002\%20O urSchOurFuture.pdf

16. Rockoff et al EFandP2011.pdf [Internet]. [cited 2017 Dec 13]. Available from: https://www.dartmouth.edu/ dstaiger/Pape rs/2011/Rockoff\%20et\%20al\%20EFandP2 011.pdf

17. Thomas S. Dee, Martin R. West. The NonCognitive Returns to Class Size. Educ Eval Policy Anal. 2011 Mar 1;33(1):2346.

18. Hanushek EA, Woessmann L. Do better schools lead to more growth? Cognitive skills, economic outcomes, and causation. J Econ Growth. 2012 Dec 1;17(4):267321. 